\title{
膀胱癌に随伴する上皮内癌・上皮異形成の予後的意義
}

\author{
信州大学医学部泌尿器科（主任：小川秋實教授） \\ 和食正 久

\section{PROGNOSTIC SIGNIFICANCE OF CARCINOMA IN SITU AND EPITHELIAL DYSPLASIA ACCOMPANYING BLADDER CANCERS} \\ Masahisa Wajiki \\ Department of Urology, Shinshu University School of Medicine \\ (Directer: Prof. Akimi Ogawa)
}

(Purpose) We determined whether patients with bladder cancers accompanied by carcinoma in situ (CIS) or epithelial dysplasia carry a poor prognosis.

(Materials and Methods) The resected bladders from 57 patients with a bladder cancer were step-sectioned. The stained specimens underwent microscopic examination and the extent of CIS and epithelial dysplasia was mapped out. The 57 patients were followed up for 5 to 10 years and the cumulative survival rates were calculated.

(Results) Gross tumors were accompanied by CIS in 29 (51\%) patients and by epithelial dysplasia in $52(91 \%)$ patients. The survival rates did not differ significantly between the presence and absence of the accompanying mucosal lesions. However, the cancer specific survival rates were higher in patients with accompanying CIS located away from the gross tumor than in patietns with CIS located adjacent to the gross tumor $(p=0.04)$. In patients with a non-papillary bladder cancer the survival rates tended to be higher when accompanying epithelial dysplasia accounted for over $3 \%$ of the whole mucasal area than when it accounted for less than $3 \%(\mathrm{p}=$ 0.09).

(Conclusions) These results suggest that the presence of accompanying CIS or Epithelial dysplasia does not indicated a poor prognosis, and may indicate a favorable prognosis in patients with a non-papillary bladder cancer.

Key words: carcinoma in situ, dysplasia, cystectomy

要旨：(目的）上皮内癌・上皮異形成の随伴が膀胱癌の予後因子となるかを調べた.

（方法）膀胱全摘除術を行った膀胱癌57例の上皮内癌および上皮異形成の随伴の有無を組織学的に観 察してマッピングを行うともに，累積生存率を検討した。

（結果）上皮内癌の随伴を 29 例（51\%）に，上皮異形成の随伴を52例（91\%）に認めた。これらの上 皮内病変の随伴の有無による累積生存率に有意差はなかった。しかし，上皮内癌の随伴が隆起性腫瘍の 周囲に連続している場合より，離れた部位にも散在している場合のほうが癌特異累積生存率が高かった $(\mathrm{p}=0.04)$. 非乳頭状癌では, 上皮異形成の随伴面積が $3 \%$ 以上の症例が随伴面積 $3 \%$ 未満の症例よりも 累積生存率が高い傾向であった $(\mathrm{p}=0.09)$.

(結論) 膀胱癌での上皮内癌・上皮異形成の随伴は予後不良を示すものではなく, 特に非乳頭状癌で は予後のよい場合もあることが示唆された。

キーワード：上皮内癌，上皮異形成，膀胱全摘除術

緒言 隆起性の膀胱腫瘍に上皮内癌・上皮異形成が随伴す
ることについては1952年に Melicow が最初に報告 し1)，その後腫瘍の膀胱再発・多発との関係や腫瘍増殖 
様式の解明のためこれら随伴病変に対する多くの研究 がなされ2) 4)，随伴だけではなく前癌病変としても重 要視されるようになった。膀胱癌の性格によってこれ らの病変の随伴の様子は異なることが考えられ，もし そうならば随伴病変の有無, 異型の程度, 位置, 範囲 などが予後関連因子となる可能性がある．表在性膀胱 癌では上皮内癌が合併しているほうが予後が悪いとす

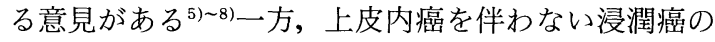
なかに進行が早く予後の悪いものがあるとも言われて いる ${ }^{9)}$.また, 我々の経験では随伴病変が多いほど治療 成績が悪いとは限らない。このように，これらの随伴 病変は必ずしも再発多発の絶対条件ではなく，また予 後の確定因子とも言えず ${ }^{10)}$, 随伴病変の持つ意味合い にはいまだ不明な点がある。そのような観点から，こ れらの随伴病変, すなわち上皮内癌, 上皮異形成の存 在が膀胼癌の予後とどのような関連があるかを知る必 要がある。そこで我々は膀胱全摘除術を受けた症例に ついて, 摘出標本上の随伴病変の有無および随伴の範 囲を詳細に調べ術後遠隔成績との関連について検討し た.

\section{対象・方法}

1978年から1984年までの 7 年間に信州大学医学部附 属病院において膀胱全摘除術を行った膀腃原発移行上 皮癌症例82例のうち, 摘出膀胱の全割標本が得られ組 織学的に観察可能であった57例を対象とした．除外症 例は，全割に適さない固定，染色上の問題扔よび切片
の紛失のため全摘標本のマッピングができなかった症 例であり，作為の加わった可能性は少ない．57例のう ち男性は45例，女性は12例で，年齢は37歳から88歳ま で平均68歳であった．39例には放射線12〜16Gy を術 前 $2 \sim 4$ 日前までの $3 \sim 4$ 日間に照射し，4 例には全 摘除術の $3 \sim 6$ 力月前に $30 \mathrm{~Gy}$ 以上の放射線照射をし た。また，75歳以下の35例では膀胱摘除と同時に骨盤 内リンパ節郭清を行った。

摘出膀胱はホルマリン固定し, およそ6mm の幅で全 割した。膀胱の切り開き方は，ホルマリン注入にて固 定後切り開いたものと，尿道，膀胱前壁を正中線で切 り開き固定したものとがあり，また切り出し方向も水 平方向と矢状方向とがあり，必ずしも膀胱癌取扱い規 約 $(\text { 日本泌尿器科学会, 日本病理学会編 })^{11}$ に従ってい ない.すべての切片は Hematoxylin-Eosin 染色を行 い，同一検者が光学顕微鏡で観察した。標本切片数は 全体で1,997枚，1症例あたり平均35枚であったが, 粘 膜面が切片上に全く薄切されていないものを除くと 1,882枚， 1 症例あたり平均33枚であった。

1 症例ごとに隆起性腫瘍，上皮内癌，上皮異形成， 上皮過形成についてマッピングを行った。マッピング した 2 症例について図 1 に示す．腫瘍の発育様式，異 型度, 深達度については膀胱癌取扱い規約に従って分 類したが，発育様式では潰瘍状・浸潤型は非乳頭状・ 浸潤型に含めた。上皮内癌・上皮異形成は Nagy らの 分類 ${ }^{12)}$ に準じた。すなわち，両者共に非乳頭状で粘膜内

図 1 膀胱全摘標本のマッピング

左は乳頭状癌の 1 例で上皮内癌が腫瘍から離れた部位にも散在して随伴している. 右 は非乳頭状癌の 1 例で上皮内癌が腫瘍周囲にのみ随伴している.



PIT G3 pT3b

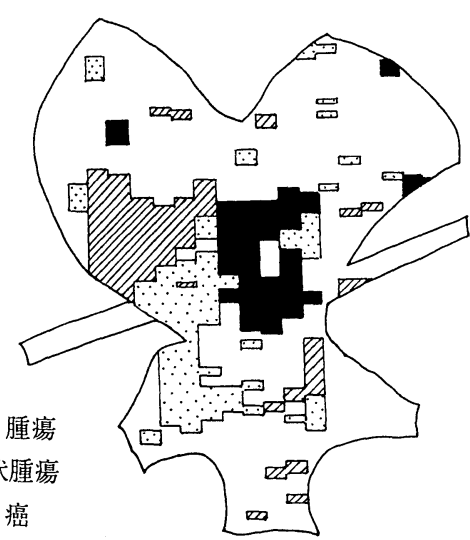

NIT G3 pT1b 
図 2 上皮内病変の組織所見 上段は上皮内癌，中段が中等度の異形成，下段は異型 が少なく過形成とした。
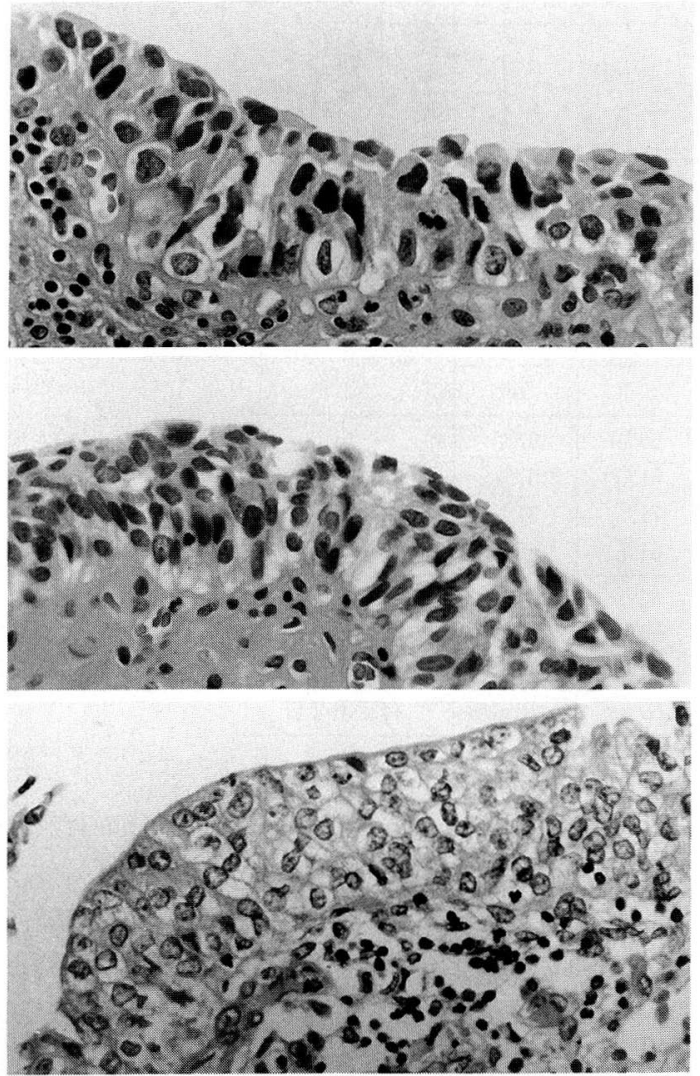

に留まっており基底膜を破る浸潤を示さない病変であ $\eta ，$ 上皮内癌は WHO 分類による移行上皮癌 Grade 3 に相当する高度の異型を示すもの，上皮異形成は Grade 1, 2に相当する異型を示すものとした. ただし， 非隆起性でごく軽度の異型（軽度の Grade 1相当）を 示す場合は，正常上皮または上皮過形成との区別は難 しいため上皮異形成加ら除外した。図 2 に異形成の組 織所見の代表例を示す.なお, Nagy らは高度の異型を 示す細胞が存在するにもかかわらず全層を占めていな い場合は高度の異形成としているが，ここでは高度の 異型を示す細胞が 2 層以上で，かつ上皮層の半分以上 を占めているか，または上皮内癌に連続している場合 には上皮内癌として扱った。

各症例について全薄切切片中に占める上皮内癌, 上 皮異形成の範囲の割合，すなわち薄切切片の粘膜面の 長さの合計に対するそれぞれの随伴病変の長さの合計 の占める割合を，随伴面積率として求めた。この比率
表 1 全症例の組織学的異型度と病理学的深達度

\begin{tabular}{c|ccrrrr}
\hline \multirow{2}{*}{ 異型度 } & \multicolumn{7}{|c}{ 深 達 度 } \\
\cline { 2 - 7 } & pTa & pTis & pT1 & pT2 & pT3 & pT4 \\
\hline G1 & 2 & & & & & \\
G2 & 3 & 1 & 7 & 1 & 1 & 2 \\
G3 & & 4 & 11 & 5 & 17 & 3 \\
\hline
\end{tabular}

は標本粘膜面すなわち膀腅内腔面の全面積に占める 各々の随伴病変の面積の割合に近似できると考える。

各症例の術後経過を診療録と患者への質問状郵送に よって調査し，1989年 8 月15日の時点における生死お よび癌死の有無を確認した。生存率を Kaplan-Meier 法により累積生存率として算出し同時に癌特異累積生 存率 (cancer specific survival) も算出した. 生存率 曲線の差について一般化 Wilcoxon 検定を行い, 3 年, 5 年累積生存率の有意差の検定は標準誤差に基づく検

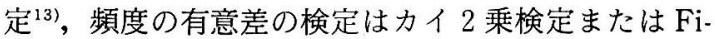
sher の直接確率計算によった。危険率 $5 \%$ 以下を有 意，10\%以下を傾向ありとした。

\section{結果}

表 1 に57例の腫場深達度と異型度を示す．原発性上 皮内癌の 2 例を含め, 57 例のうち上皮内癌の随伴を 29 例（51\%）に，上皮異形成の随伴を52例（91\%）に認 めた。 1 例ごとに全切片中に占める随伴病変の割合を 膀胱内腔全面積に対する随伴面積率として算出したと ころ, 上皮内癌随伴 29 例に抢けるその随伴面積比率は $0.3 \sim 15.8 \%$ （中央值は2.7\%）であり，また上皮異形 成随伴52例におけるその随伴面積比率は $0.1 \%$ 〜 $16.5 \%$ （中央值は $2.9 \%$ ）であった．上皮内癌の随伴 面積比率が $3 \%$ 以上におよぶ症例は14例(25\%)，上皮 異形成の随伴面積比率が $3 \%$ 以上におよぶ症例は 25 例 （44\%）であった。

表 2 に腫佰発育様式別の上皮病変随伴頻度を示す。 上皮内癌の随伴は乳頭状癌に比し非乳頭状癌に有意に 多かった $(p=0.005)$. 上皮内癌の随伴部位について は, 乳頭状癌では腫瘍周囲のみに伴う症例が 4 例, 腫 晹と離れた部位にも伴なった症例が 4 例であるのに対 し，非乳頭状癌では周囲のみが 4 例，離れて伴なった もの17例であったが，この頻度は有意な差ではなかっ た。上皮異形成についても，乳頭状癌では腫瘍周囲の みの随伴が 7 例, 離れた部位にも存在する随伴が16例 で, 非乳頭状癌では各々 7 例, 22例であり, 発育樣式 による頻度の差はなかった。

随伴病変と異型度との関連を見たところ，上皮内癌 
表 2 上皮内癌・ 上皮異形成の随伴症例数

\begin{tabular}{c|c|c|c|c|c|c}
\hline & \multicolumn{3}{|c|}{ 上皮内癌随伴面積比率 } & \multicolumn{3}{|c}{ 上皮異形成随伴面積比率 } \\
\cline { 2 - 7 } & $0 \%$ & $0-3 \%$ & $\geqq 3 \%$ & $0 \%$ & $0-3 \%$ & $\geqq 3 \%$ \\
\hline $\left.\begin{array}{c}\text { 乳頭状癌 } \\
(\mathrm{n}=27) \\
\begin{array}{c}\text { 非乳頭状癌 } \\
(\mathrm{n}=30)\end{array}\end{array}\right)$ & 19 & 3 & 5 & 4 & 11 & 12 \\
\hline 計 $(\mathrm{n}=57)$ & 28 & 15 & 14 & 5 & 27 & 25 \\
\hline
\end{tabular}

表 3 上皮内病変の随伴と累積生存率

\begin{tabular}{|c|c|c|c|c|c|}
\hline \multirow{2}{*}{ 随伴病変 } & \multirow{2}{*}{ 随伴面積比率 } & \multirow{2}{*}{ 症例数 } & \multicolumn{2}{|c|}{ 累積生存率 } & \multirow{2}{*}{$\begin{array}{l}\text { 一般化 Wilcoxon } \\
\text { 検定 }\end{array}$} \\
\hline & & & 3 年 & 5 年 & \\
\hline 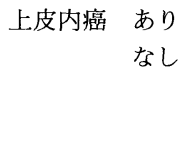 & $\begin{array}{l}3 \% \text { 以上 } \\
0 \% \sim 3 \% \text { 未満 }\end{array}$ & $\begin{array}{l}29 \\
28 \\
14 \\
43\end{array}$ & $\begin{array}{l}66 \% \\
61 \% \\
71 \% \\
61 \%\end{array}$ & $\begin{array}{l}62 \% \\
57 \% \\
71 \% \\
55 \%\end{array}$ & $\begin{array}{l}\text { 有意差なし } \\
\text { 有意差なし }\end{array}$ \\
\hline $\begin{array}{r}\text { 上皮異形成あり } \\
\text { なし }\end{array}$ & $\begin{array}{l}3 \% \text { 以上 } \\
0 \% \sim 3 \% \text { 未満 }\end{array}$ & $\begin{array}{r}52 \\
5 \\
25 \\
32\end{array}$ & $\begin{array}{l}65 \% \\
40 \% \\
68 \% \\
59 \%\end{array}$ & $\begin{array}{l}61 \% \\
40 \% \\
63 \% \\
56 \%\end{array}$ & $\begin{array}{l}\text { 有意差なし } \\
\text { 有意差なし }\end{array}$ \\
\hline
\end{tabular}

図 3 上皮内癌随伴の有無別の累積生存率

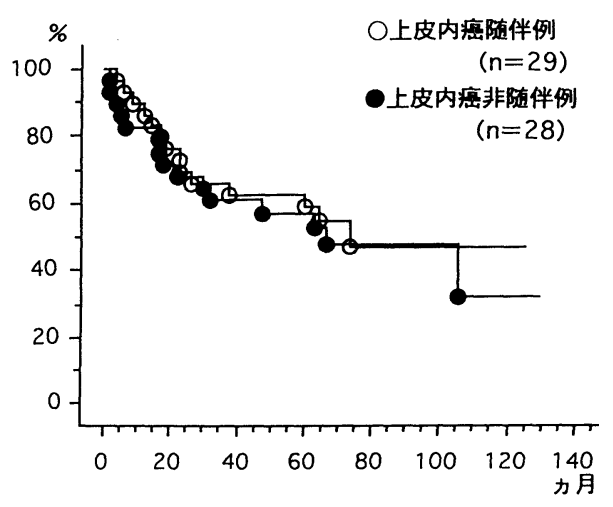

随伴が G1ないし G2017例では全くなかったのに対し G3では40例のうち29例にみられ, 有意差を認めた。し かし上皮異形成では関連がなかった。また上皮内癌, 上皮異形成共に随伴と深達度, 脈管侵襲の有無抢よび 術前照射とは関連がなかった。

生存についての調査では, 1989 年 8 月 15 日の最終調 査時に54例の生死を確認できたが, 3 例は 2 年 9 カ月 から 3 年 (平均 2 年11力月) までに追跡不能となった。 最終観察時に生存していたのは28例で, 癌死が18例, 癌なしの他因死が 9 例, 死因不明が 2 例であった. 死 因不明の 2 例は, 共に G2で pT1以下であり術後 2 年
まで再発を認めていなかったが，死亡時の癌の有無は 不明であった。癌ありの生存はなかった。

表 3 に上皮内癌・上皮異形成の随伴の有無別と随伴 面積比率別の累積生存率を, 図 3 に随伴上皮内癌の有 無別の生存率曲線を示す。上皮内癌または上皮異形成 の随伴の有無で 3 年, 5 年累積生存率および癌特異累 積生存率に有意差は認められなかった。 また, それら の随伴面積比率が $3 \%$ 以上と $3 \%$ 未満（随伴しないも のを含む）とに別けた場合も有意差はなかった。図 4 に上皮内癌の随伴部位別の累積生存率と癌特異累積生 存率を示す。累積生存率では両者間に有意差を認めな かったが, 癌特異累積生存率では有意差を認め, 上皮 内癌が腫瘍から離れて随伴するほうが成績がよかった $(\mathrm{p}=0.04)$.一方, 上皮異形成では随伴部位別の累積生 存率に有意差はなかった。

表 4 亿乳頭状癌症例での上皮病変随伴の有無と随伴 面積比率別にみた累積生存率を示す。上皮内癌または 上皮異形成の随伴の有無, あるいはその随伴面積比率 が $3 \%$ 以上か否かによる累積生存率および癌特異累積 生存率に有意差はなかった。

表 5 に同じく, 非乳頭状癌症例での累積生存率を, 図 5 に上皮異形成の随伴面積比率別の累積生存率と癌 特異累積生存率を示す.上皮内癌の随伴の有無, ある いはその随伴面積比率が 3 \%以上か否かによる累積生 
図 4 上皮内癌の随伴部位別の累積生存率（左）と癌特異累積生存率（右）
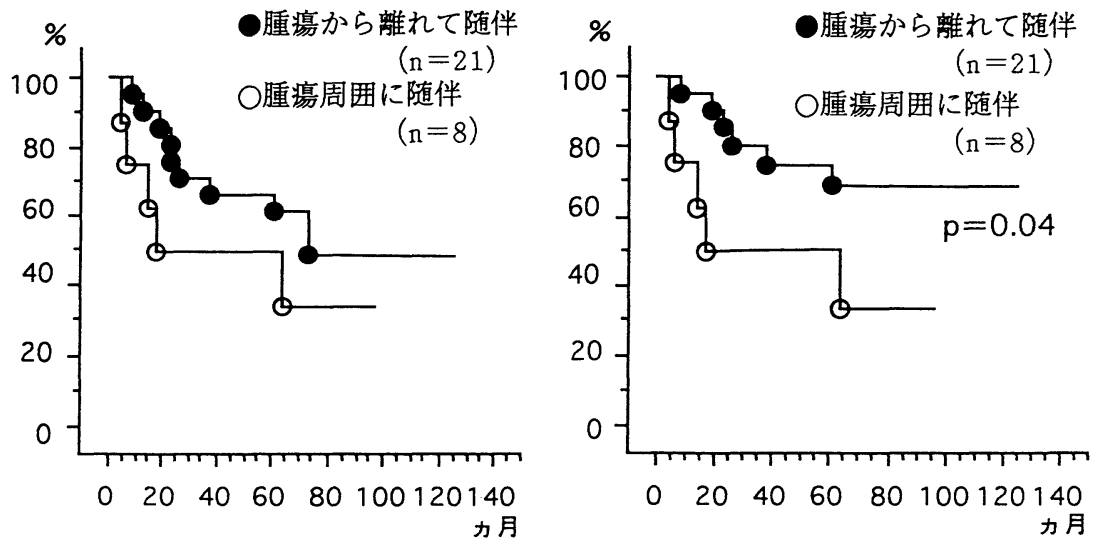

表 4 乳頭状癌症例での上皮病変の随伴と累積生存率

\begin{tabular}{|c|c|c|c|c|c|c|}
\hline \multirow{2}{*}{\multicolumn{2}{|c|}{ 随伴病変 }} & \multirow{2}{*}{ 随伴面積比率 } & \multirow{2}{*}{ 症例数 } & \multicolumn{2}{|c|}{ 累積生存率 } & \multirow{2}{*}{$\begin{array}{c}\text { 一般化 Wilcoxon } \\
\text { 検定 }\end{array}$} \\
\hline & & & & 3 年 & 5 年 & \\
\hline \multirow[t]{4}{*}{ 上皮内癌 } & あり & & 8 & $50 \%$ & $50 \%$ & \\
\hline & なし & & 19 & $68 \%$ & $62 \%$ & 有意差なし \\
\hline & & $3 \%$ 以上 & 5 & $60 \%$ & $60 \%$ & \\
\hline & & $0 \%$ $3 \%$ 末満 & 22 & $64 \%$ & $58 \%$ & 有意差なし \\
\hline \multicolumn{2}{|c|}{ 上皮異形成あり } & & 23 & $65 \%$ & $60 \%$ & \\
\hline \multirow{3}{*}{\multicolumn{2}{|c|}{ なし }} & & 4 & $50 \%$ & $50 \%$ & 有意差なし \\
\hline & & $3 \%$ 以上 & 12 & $50 \%$ & $50 \%$ & \\
\hline & & $0 \% \sim 3 \%$ 末満 & 15 & $73 \%$ & $67 \%$ & 有意差なし \\
\hline
\end{tabular}

表 5 非乳頭状癌症例での上皮病変の随伴と累積生存率

\begin{tabular}{|c|c|c|c|c|c|c|}
\hline \multirow{2}{*}{\multicolumn{2}{|c|}{ 随伴病変 }} & \multirow{2}{*}{ 随伴面積比率 } & \multirow{2}{*}{ 症例数 } & \multicolumn{2}{|c|}{ 累積生存率 } & \multirow{2}{*}{$\begin{array}{c}\text { 一般化 Wilcoxon } \\
\text { 検定 }\end{array}$} \\
\hline & & & & 3 年 & 5 年 & \\
\hline \multirow[t]{4}{*}{ 上皮内癌 } & あり & & 21 & $71 \%$ & $66 \%$ & \\
\hline & なし & & 9 & $44 \%$ & $44 \%$ & 有意差なし \\
\hline & & $3 \%$ 以上 & 9 & $78 \%$ & $78 \%$ & \\
\hline & & $0 \%$ ～ $3 \%$ 末満 & 21 & $57 \%$ & $52 \%$ & 有意差なし \\
\hline \multirow{4}{*}{\multicolumn{2}{|c|}{$\begin{array}{r}\text { 上皮異形成あり } \\
\text { なし }\end{array}$}} & & 29 & $66 \%$ & $62 \%$ & \\
\hline & & & 1 & $0 \%$ & $0 \%$ & \\
\hline & & $3 \%$ 以上 & 13 & $85 \%$ & $76 \%$ & \\
\hline & & $0 \%$ ～ $3 \%$ 末満 & 17 & $47 \%$ & $47 \%$ & $\mathrm{p}=0.09$ \\
\hline
\end{tabular}

存率および癌特異累積生存率に有意差はなかった。 上 皮異形成を随伴しない非乳頭状癌は 1 力月で他因死し た 1 例のみで, 上皮異形成の随伴の有無による生存率 の差を判定できなかった. 上皮異形成の随伴面積比率 が $3 \%$ 以上か否かで見ると, 累積生存率は $3 \%$ 以上の 症例のほうが $3 \%$ 末満または随伴しない症例よりも高 い傾向であった $(\mathrm{p}=0.09)$.これは癌特異累積生存率
で見ても同じ傾向であった $(\mathrm{p}=0.096)$. 標準誤差に基 づく検定からは, 随伴面積率が $3 \%$ 以上の症例は 3 年 生存率が有意に高く $(\mathrm{p}=0.02), 5$ 年生存率でも有意 差はないが高い傾向であった $(\mathrm{p}=0.09)$. 癌特異累積 生存率でも 3 年生存率は有意に高い $(\mathrm{p}=0.02)$ が, 5 年生存率は有意差がなかった. 表 6 にこの両群の背景 因子を示す。背景因子は両群間に有意差を認めなかっ 
図 5 非乳頭状癌における上皮異形成の随伴面積比率別の累積生存率（左）と癌特異 累積生存率（右）
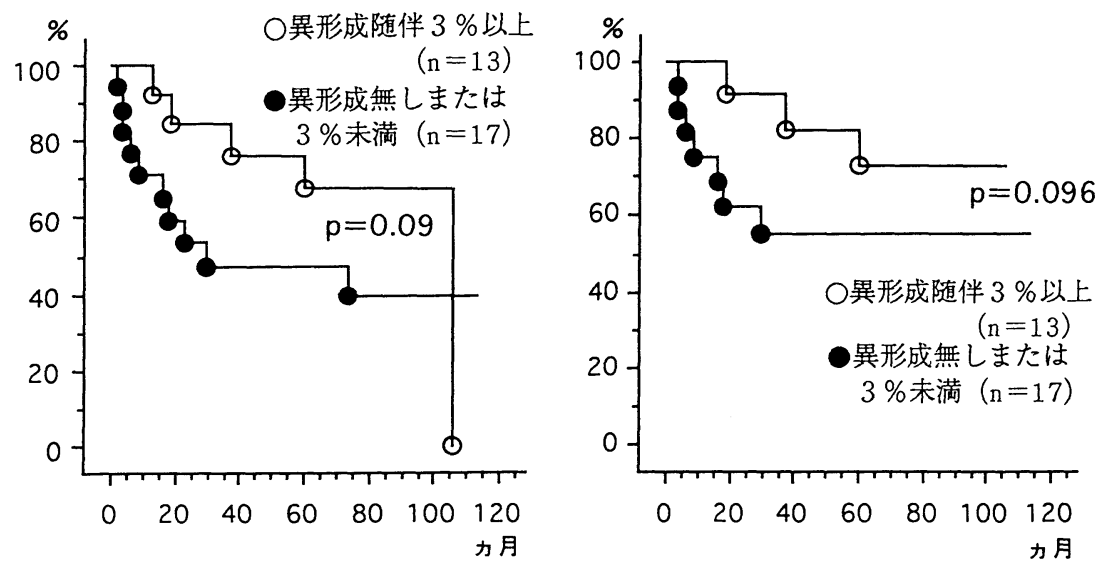

表 6 上皮異形成の随伴面積比率で分類した非乳頭状癌 2 群の背景因子

\begin{tabular}{|c|c|c|c|c|c|c|c|c|c|c|c|}
\hline \multirow{2}{*}{$\begin{array}{l}\text { 異形成随伴 } \\
\text { 面積比 (例数) }\end{array}$} & \multirow{2}{*}{$\begin{array}{c}\text { 平均年齢 } \\
\text { (歳) }\end{array}$} & \multicolumn{2}{|c|}{ 異型度 } & \multicolumn{2}{|c|}{ 深達度 } & \multicolumn{2}{|c|}{ 脈管侵襲 } & \multicolumn{2}{|c|}{ 放射線療法 } & \multicolumn{2}{|c|}{ 化学療法 } \\
\hline & & G2 & G3 & PT0-1 & pT2-4 & なし & あり & あり & なし & あり & なし \\
\hline $3 \%$ 末満（17例） & 67 & 1 & 16 & 5 & 12 & 4 & 8 & 15 & 2 & 3 & 14 \\
\hline $3 \%$ 以上（13例） & 71 & 1 & 14 & 6 & 15 & 6 & 11 & 12 & 1 & 4 & 9 \\
\hline
\end{tabular}

た。なお，他のそれぞれの比較においても背景因子と しての術前放射線療法の有無に差を認めなかった。

\section{考 察}

膀胱上皮病変としての上皮内癌・上皮異形成の随伴 が膀胱癌の予後に関連するか否かについては明確にさ れていない. 本研究では1982年に Nagy らが提唱した 上皮病変の分類 ${ }^{12)}$ を採用し, 膀胱癌のため全摘除した 膀胱を全割し, 微細な上皮病変の存在を見逃さないよ う詳細に観察してマッピングを行ったところ，上皮内 癌は $51 \%$ ，上皮異形成は $91 \%$ 症例に随伴していた。

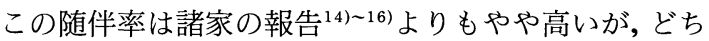
らの随伴とも半数以上が膀胱粘膜面の $3 \%$ 未満の面積 を占めるのみであり，3\%以上に及ぶ随伴は上皮内癌 が全症例の $25 \%$ ，上皮異形成が全症例の $44 \%$ で，これ らは諸家の全体の随伴率と近い值となる。このことは, 隆起性腫瘍の周囲を含め膀胱内腔全体を $1 \mathrm{~mm}$ 以下の 病変を見逃さないよう詳細に観察することにより, $3 \%$ 末満の小さな随伴を捉えたために随伴率が高く なった可能性を示唆している. なお, 上皮内癌の随伴 は乳頭状癌よりも非乳頭状癌に多くみられたが，原発 性上皮内癌から発生した腫瘍が混在していたためと思 われる。
随伴上皮病変の有無と膀胱全摘除術後成績との関連 をみると, 全体の随伴上皮病変の有無と生存率との関 連性は殆どなかったが，上皮内癌の随伴が腫瘍周囲に 連続して伴う症例と腫瘍と離れた部位にも随伴する症 例とを比べてみると, 累積生存率に有意差はないもの の癌特異累積生存率は腫瘍から離れた部位に随伴する 方が有意に生存率が高かった。非乳頭状癌で随伴面積 が $3 \%$ 以上の上皮異形成を伴う群は随伴がなしまたは $3 \%$ 未満の群よりも生存率が高い傾向が認められた。 症例数が少ないため決定的な有意差が得られなかった が，これらの結果から少なくとも膀胱癌における上皮 内癌・上皮異形成の随伴は，予後不良と言うわけでは なく, 非乳頭状癌ではむしろ随伴している方が予後が よい場合があると言える。

随伴病変が予後と関連するとする報告5) 8) は多い. ほとんどは表在性腫瘍について論じており，多くは上 皮内病変が随伴するほうが再発の危険性が高いとして いる.しかし生命予後との関連については明確ではな く, 本研究でそれらと一見異なる結果となったのは, 対象が全摘標本で上皮内癌からの発生を思わせる腫瘍 や浸潤性腫瘍を含んでおり，しかも生存率そのものを 検討したからと考えられ,矛盾した結果とは言えない. 
隆起性病変とこれら随伴病変の発育発展様式は, 上 皮内癌・上皮異形成がある程度の範囲に発生した後に その一部が隆起性病変へと発展する場合と, 隆起性病 変がある程度発育してからそれら随伴病変が続発的に 形成されていく場合とが考えられる. 上皮内病変を随 伴するほうが予後がよい場合の病態を推察してみる と, もし上皮内癌・上皮異形成が先に発生したとすれ ば，その発育速度が緩慢でなかなか隆起性病変になら ず，隆起性になっても浸潤性の弱い悪性度の低い腫瘍 である場合が考えられ，一方もし隆起性病変が先行し たとすれば，その発育浸潤速度が緩徐であるためにそ の間に上皮内癌・上皮異形成が随伴する余裕があり続 発するものと考えられる. 膀胱の多発腫瘍が同じ起源 の細胞からなるという推測 ${ }^{17)}$ が正しいとするなら, 隆 起性腫瘍が随伴上皮内病変と同じ起源の細胞から成り 立っていて，新生物ではあっても浸潤しにくいと言う 上皮内癌の一部や上皮異形成の性質 ${ }^{18)}$ が隆起性腫瘍に も共通して存在する可能性がある.つまり上皮内病変 が広範囲に随伴する膀胱癌の方が随伴がないか少ない 膀胱癌よりも腫瘍の持つ本来の浸潤性や増殖転移能力 が劣る場合があると言う推察が成り立つ. 特に上皮異 形成はその悪性度が低く, それを多く随伴する膀胱癌 が悪性度の低い性質を持っている可能性が考えられ る.

以上のことから, 上皮内癌, 上皮異形成の随伴の有 無, 程度は決定的な予後関連因子ではないが, 考虑す る意義があると考えられる。特に非乳頭状癌ではこれ らを随伴するほうが全摘除術後の成績がよい場合もあ ることは, 膀胱癌の発育発展様式を知る上で参考にな る.

稿を終えるにあたり, 御指導, 御校閲を賜わりました信州 大学小川秋實学長, ならびに病理組織学の基礎について御 指導賜わりました同医学部重松秀一教授に樑く感謝申し上 げます。

\section{文 献}

1) Melicow, M.M.: Histological study of vesical urothelium intervening between gross neoplasms in total cystectomy. J. Urol., 68, 261279, 1952.

2) Koss, L.G.: Mapping of the urinary bladder: Its impact on the concepts of bladder cancer. Hum. Pathol., 10, 533-548, 1979.

3) Murphy, W.M., Nagy, G.K., Rao, M.K., Soloway, M.S., Parija, G.C., Cox, C.E. II and Friedell, G.H.: "Normal" urothelium in patients with bladder cancer. Cancer, 44, 1050
$-1058,1979$.

4) Mostofi, F.K. and Sesterhenn, I.A.: Pathology of epithelial tumors and carcinoma in situ of bladder. Prog. Clin. Biol. Res., 162A, 55-74, 1984.

5) Smith, G., Elton, R.A., Beynon, L.L., Newsam, J. E., Chisholm, G.D. and Hargreave, T.B.: Prognostic significance of biopsy results of normallooking mucosa in cases of superficial bladder cancer. Brit. J. Urol., 55, 665-669, 1983.

6) Kiemeney, L.A.L.M., Witjes, J.A., Heijbroek, R. P., Verbeek, A.L.M. and Debruyne, F.M.J.: Predictability of recurrent and progressive disease in individual patients with primary superficial bladder cancer. J. Urol., 150, 60-64, 1993.

7) Althousen, A.F., Prout, G.R. Jr. and Daly, J.J. : Non-invasive papillary carcinoma of the bladder associated with carcinoma in situ. J. Urol., 116, 575-580, 1976.

8) Wolf, H. and Hojaard, K.: Prognostic factors in local surgical treatment of invasive bladder cancer, with special reference to the presence of urothelial dysplasia. Cancer 51, 1710-1715, 1983.

9) Kakizoe, T., Matsumoto, K., Nishio, Y. and Kishi, K.: Analysis of 90 stepsectioned cystectomized specimens of bladder cancer. J. Urol., 131, 467-472, 1984.

10) Quilty, P.M., Hargreave, T.B., Smith, G. and Duncan, W.: Do normal mucosal biopsis predict prognosis in patients with transitional cell carcinoma of bladder treated by radical radiotherapy? Brit. J. Urol., 59, 242-247, 1987.

11) 日本泌尿器科学会, 日本病理学会編: 膀胱癌取扱 い規約. 第 2 版, 金原出版, 第 2 部, 病理学的事項, p71-96, 1993.

12) Nagy, G.K., Frable, W.J. and Murphy, W.M.: Classification of premalignant urothelial abnormalities, a Delphi study of NBCCGA. Pathol. Ann., 17, 219-233, 1982.

13）日本癌治療学会癌規約総論委員会編：日本癌治療 学会·癌規約総論, 金原出版, II. 生存率規約, p10 -33, 1991.

14) Schade, R.O. and Swinney, J.: Precancerous changes in bladder epithelium. Lancet, 2, 943946, 1968.

15) Cooper, P.H., Waisman, J., Johnston, W.H. and Skinner, D.G.: Severe atypia of transitional epithelium and carcinoma of the urinary bladder. Cancer, 31, 1055-1060, 1973.

16) Skinner, D.G., Richie, J.P., Cooper, P.H., Wais- 
man, J. and Kaufman, J.J.: The clinical significance of carcinoma in situ of the bladder and its association with overt carcinoma. J. Urol., 112, 68-71, 1974.

17) Sidransky, D., Frost, P., Von Eschenbach, A., Oyasu, R., Preisinger, A.C. and Vogelstein, B. : Clonal origin of bladder cancer. N. Engl. J.
Med., 326, 734-740, 1992.

18) Weinstein, R.S.: Evolving concepts of the cancer cell. In Bladder Cancer: A.U.A. Monographs in Urology, vol. 1, p3-11, Williams \& Wilkins, Baltimore, 1982.

(1996年 3 月 7 日受付， 9 月 6 日受理，特別掲載） 